\title{
Avaliação de pisos táteis como elemento de wayfinding em escola de ensino especial para crianças com deficiência visual
}

\author{
Evaluation of tactile floors as a wayfinding element in a \\ special-needs school for children with visual impairment
}

\section{Tania Pietzschke Abate Doris Catharine Cornelie Knatz Kowaltowski}

\section{Resumo \\ $\mathbf{E}$}

ste artigo busca analisar a orientação espacial dos alunos com deficiência visual em escola de educação especial localizada na cidade de São Paulo antes e após a implantação de sinalização tátil no piso, importante elemento do sistema chamado wayfinding. Na primeira etapa da pesquisa (período entre outubro e dezembro de 2012), foram realizadas observações com os alunos (pré-escola e ensino fundamental) com deficiência visual (cegueira e baixa visão) para avaliação da orientação durante a circulação no edifício escolar. Após a reforma do piso existente em 2014, as autoras implantaram a sinalização tátil no piso (ABNT, 2004) na área de circulação e iniciaram a segunda etapa da pesquisa (período entre agosto e setembro de 2014), com novas observações. Foram consideradas as premissas adotadas para a definição da unidade estudo de caso e os critérios de escolha do instrumento de coleta de dados. Constatou-se que a implantação da sinalização tátil no piso nas áreas de circulação de alunos com deficiência visual requer familiarização com o uso, iniciada por meio de treinamento de orientação e mobilidade (O\&M); disponibilização e aprendizado de uso concomitante do mapa tátil; adoção da bengala de rastreamento; escalonamento dos horários de intervalo das diferentes classes; definição de mãos de direção; segurança no trajeto e monitoramento.

Palavras-chaves: Arquitetura escolar. Wayfinding. Acessibilidade espacial. Sinalização tátil.

\begin{abstract}
This article aims to analyze the spatial orientation of visually impaired students in a special education school in the city of São Paulo, before and after the installation of tactile tiles, an important element in the system called wayfinding. In the first phase of the study (October to December, 2012), observations were made with pre-school and elementary school students with visual impairment (blindness and low vision) for evaluation of orientation while moving around in the school building. After a renovation of the existing flooring in 2014, the authors installed tactile signage on the floor (ABNT NBR/9050, 2004) in the circulation areas and initiated the second phase of the study (August and September, 2014) with new observations. The adopted assumptions were considered for determining the case study unit and the criteria for choosing the data collection tool. The study showed that the implementation of tactile signage on the floor in the circulation areas of visually impaired students requires familiarity with its use through guidance and mobility training $(O \& M)$, availability and concomitant use of tactile maps, adoption of directional walking sticks, different recess schedules for different classes, definition of circulation paths, security in circulation, and monitoring.

Keywords: School architecture. Wayfinding. Spatial accessibility. Tactile signage.
\end{abstract}

ABATE, T. P.; KOWALTOWSKI, D. C. C. K. Avaliação de pisos táteis como elemento de wayfinding em escola de ensino 53 especial para crianças com deficiência visual. Ambiente Construído, Porto Alegre, v. 17, n. 2, p. 53-71, abr./jun. 2017. ISSN 1678-8621 Associação Nacional de Tecnologia do Ambiente Construído.

http://dx.doi.org/10.1590/s1678-86212017000200146 


\section{Introdução}

Segundo Felippe (2004, p. 5),

[...] a orientação é o aprendizado no uso dos sentidos para obter informações do ambiente. Saber onde está, para onde quer ir e como fazer para chegar ao local desejado. [...] A mobilidade é o aprendizado para o controle dos movimentos de forma organizada e eficazatributos do ser humano [...].

Destaca-se que a orientação é interdependente das habilidades do indivíduo e das condições de seu meio ambiente.

Segundo o artigo $5^{\circ}\left(\S 1^{\circ}\right)$ do Decreto Federal no 5.296 (BRASIL, 2004), a deficiência visual é definida como,

\section{[...] cegueira, na qual a acuidade visual é igual ou menor que 0,05 no melhor olho, com a melhor correção óptica; a baixa visão, que significa acuidade visual entre 0,3 e 0,05 no melhor olho, com a melhor correção óptica; os casos nos quais a somatória da medida do campo visual em ambos os olhos for igual ou menor que 60o; ou a ocorrência simultânea de quaisquer das condições anteriores.}

Busca-se analisar a orientação espacial dos alunos com deficiência visual na área de circulação de escola de educação especial localizada na cidade de São Paulo antes e após a implantação da sinalização tátil no piso, importante elemento do wayfinding system (PASSINI, 1984; ARTHUR; PASSINI, 1992; GOLLEDGE, 1999; GIBSON, 2009; MEUSER; POGADE, 2010). Pretende-se melhorar as condições de orientação de alunos com deficiência visual em escolas de acordo com as novas leis de inclusão no ensino e de acessibilidade.

Este estudo, além de atender à política de pesquisa da instituição envolvida, contou com a colaboração de pesquisadores com experiência, e foi realizado com respaldo de equipe multidisciplinar composta de arquitetos, educadores (professores de O\&M) e psicólogos (em momentos-chave). Esse apoio colaborou para o resultado deste trabalho, uma vez que as pesquisadoras não têm essa formação. Este artigo apresenta os resultados finais de pesquisa de pós-doutorado. Faz-se necessário discorrer sobre os conceitos de orientação espacial e wayfinding, bem como apresentar a metodologia deste estudo. Ao final, são apresentados os resultados e as considerações.

\section{Orientação espacial e wayfinding}

A percepção tátil é relevante para a pessoa com deficiência visual, pois possibilita o contato, o conhecimento dos objetos e, inclusive, a leitura por meio do sistema Braille. Para orientação e mobilidade, a audição é um dos sentidos mais importantes, pois permite estabelecer relações espaciais. O sentido vestibular ou labiríntico fornece informações sobre a posição vertical do corpo e dos componentes rotatórios e lineares dos movimentos. O olfato é um sentido que pode fornecer indícios para orientação e localização de ambientes, como a cozinha, os banheiros, os jardins e outros locais. A cinestesia é a sensibilidade para perceber os movimentos musculares ou das articulações. Essa percepção nos torna conscientes da posição e do movimento do corpo, quando se eleva o braço, por exemplo, ou quando se sobe ou se desce um plano inclinado. A memória muscular (repetição de movimentos em uma sequência fixa) é uma das funções do sentido cinestésico utilizada para subir ou descer degraus ou para trajetos curtos, sem a necessidade de contar os passos.

Segundo Felippe (2004, p. 6), a pessoa com deficiência visual pode se movimentar com a ajuda de outra pessoa (guia vidente); usando seu próprio corpo (autoproteções); usando uma bengala (bengala de rastreamento); usando um animal (cãoguia); usando a tecnologia (ajudas eletrônicas).

A autonomia para a movimentação é fundamental para o desenvolvimento integral do ser humano, pois é assim que ele interage diretamente com o espaço físico e com os elementos nele presentes (LARAMARA, 2010). "Quando uma pessoa com deficiência está em um ambiente acessível, suas atividades são preservadas, e a deficiência não afeta suas funções." (CAMBIAGHI, 2007, p. 23). "A acessibilidade é um conceito norteador de pedagogias atuais que apoiam a inclusão social de pessoas com diferentes habilidades.' (KOWALTOWSKI, 2011, p. 199).

Sabe-se que a orientação no espaço depende principalmente da percepção visual e da audição, mas também do projeto desse espaço, seja ele urbano ou dos interiores de edificações. Esse projeto, por sua vez, apresenta-se por meio da clareza do seu sistema de circulação e dos marcos presentes. Dessa forma, não devemos confundir os termos wayfinding e orientação (ou orientabilidade), pois o primeiro é um processo dinâmico e o segundo, estático. Wayfinding refere- 
se aos atributos do ambiente construído ou da escala urbana que auxiliam a orientação do usuário.

Os indivíduos deslocam-se nos ambientes por meio de movimentos orientados, e o wayfinding faz com que a pessoa seja capaz de situar-se e deslocar-se em um ambiente construído (BINSELY, 2004). Nesse contexto, entende-se que o wayfinding system pode ser constituído por elementos do desenho urbano, da arquitetura e do design.

O arquiteto Kevin Lynch (1997) utilizou o termo orientação espacial na arquitetura pela primeira vez. O seu livro A imagem da cidade (1960) é baseado no conceito de orientação espacial e no seu pré-requisito, o mapa cognitivo (imagem). Décadas depois surgiram os livros Wayfinding in architecture (PASSINI, 1984); Wayfinding: people, signs and architecture (ARTHUR; PASSINI, 1992) e Wayfinding behavior: cognitive mapping and other spatial processes (GOLLEDGE, 1999).

$\mathrm{O}$ tema wayfinding foi disseminado entre os designers gráficos, entre outros, por meio de publicações posteriores, como as de Calori (2007); Gibson (2009) e Meuser e Pogade (2010). Faz-se relevante citar a multidisciplinaridade do wayfinding (arquitetura, design gráfico, de produto e de interiores, paisagismo, entre outras). O wayfinding utiliza sinalização, pontos de referência e pistas do percurso e ambiente para auxiliar o indivíduo a navegar e se orientar espacialmente.

A expressão wayfinding system envolve elementos em um sistema que auxilia o usuário a encontrar a sua rota (orientar-se). Entre esses elementos, destacam-se a própria arquitetura e o urbanismo, que favorecem a circulação, deixam claras as entradas e saídas, os acessos verticais, a localização dos caminhos (posicionamento de mirantes em rotas urbanas de pedestres, entre outros referenciais); o design através de mapas (gráficos ou táteis); das maquetes; das placas de sinalização (teto, piso ou convencional); dos balcões de informação; dos sinalizadores e balizadores (luzes de informação); dos telefones de informação (incluindo-se aqueles para surdos), dos intercomunicadores, dos displays de vídeo e do global positioning system (GPS), entre outros.

No caso de pessoas com deficiência visual (cegas e com baixa visão), destacam-se os elementos relevantes no wayfinding system, como paredes, rodapés, guias, corrimãos e rampas, bem como a sinalização tátil no piso (elementos arquitetônicos), fontes de odor (como o paisagismo) e ruído (como as fontes de água), posição do vento e do sol (elementos naturais), entre outros.

As pessoas com baixa visão, em especial, necessitam do contraste das cores para identificarem os elementos arquitetônicos citados. A sinalização tátil no piso deve apresentar cor contrastante com a do piso adjacente.

Muitas pessoas com baixa visão utilizam a bengala de rastreamento, como os cegos, para se orientarem. Destaca-se que a sinalização tátil no piso pode ser utilizada pelas pessoas com baixa visão (com ou sem a bengala) que podem caminhar ao lado e/ou em cima da rota tátil. Segundo entrevista concedida por João Felippe, professor de orientabilidade da Associação Brasileira de Assistência ao Deficiente Visual (Laramara), entre os professores de orientabilidade não há um consenso acerca das técnicas de uso da bengala de rastreamento pelas pessoas com deficiência visual. Dessa forma, não existem referenciais mais ou menos confiáveis, pois cada indivíduo pode receber um aprendizado diferente em relação às técnicas de orientabilidade e mobilidade.

Neste estudo os alunos não usavam a bengala de rastreamento, e não se pretende avaliar a sua adoção pelas crianças na unidade-caso em questão. Salienta-se que a bengala,

\section{[...] não é um objeto que o cego perceberia, mas um instrumento com o qual ele percebe. É um apêndice do cego, uma extensão da sua síntese corporal, uma maneira própria de explorar o mundo que o cerca [...] (MASINI, 1992, p. 31).}

Segundo Felippe et al. (2004, p. 45), a idade ideal para a introdução da bengala na vida da criança é uma pergunta difícil de ser respondida, pois,

\section{[...] cada caso é um caso. Cada criança tem os seus interesses, suas necessidades, seu ritmo e sua história. Devemos respeitá- la. Quanto mais cedo melhor. As vivências pré-bengala devem ser trabalhadas tão logo a criança adquira marcha independente sem apoio [...].}

A Figura 1 ilustra a adoção da bengala de rastreamento nos anos iniciais da escola de educação especial em país europeu. Entre as diversas técnicas de O\&M, a bengala, além de um instrumento, pode ser considerada um signo da pessoa com deficiência visual, tornando-se uma identificação que evoca o significado na consciência coletiva. (SANTOS; CASTRO, 2013). 
Figura 1 - Criança com bengala

Fonte: Hazelwood School (2015).

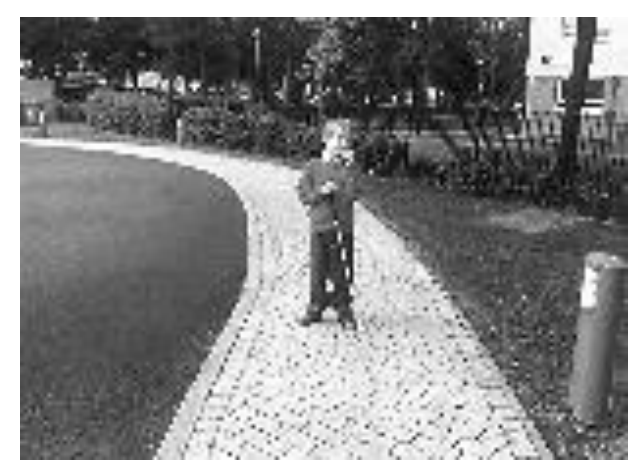

Segundo Lopes (2007, p. 319), como a NBR 9050, publicada em 1985, 1994, 2004 e 2015 pela Associação Brasileira de Normas Técnicas (ABNT),

[...] no começo dos anos 1990 com a promulgação de leis mais completas surgiu a necessidade de adequação dos espaços de uso coletivo à pessoa com deficiência acarretando na elaboração de normas técnicas $[\ldots]$

O presente estudo se baseou na versão de 2004 vigente na época da pesquisa. A definição de parâmetros específicos de acessibilidade em escolas para crianças com e sem deficiência integra outra norma técnica (de acessibilidade em escolas), cujas pesquisas tiveram início em 2006.

\section{Método}

Adotou-se como estratégia de pesquisa o estudo de caso. Este trabalho apresenta caráter qualitativo e multidisciplinar e fundamenta-se nos pressupostos teóricos da arquitetura e do desenho universal; da educação; da sociologia e da psicologia ambiental; entre outras áreas. O critério de seleção da unidade-caso apresentou caráter qualitativo: tratase da única escola gratuita no município de São Paulo que presta atendimento a alunos com deficiência visual, segundo o critério do nível pedagógico, e não da faixa etária.

A justificativa da escolha da modalidade educação especial baseia-se no fato de ocorrer, nesse local, maior número de alunos com deficiência visual na mesma escola, o que viabiliza a aplicação de instrumentos, além do aproveitamento da larga experiência da direção da escola na problemática da deficiência em questão, vivenciada no cotidiano, disponibilizando mais subsídios para a pesquisa.

Inicialmente, obteve-se a autorização para início da pesquisa com a unidade-caso e a submissão da pesquisa na Plataforma Brasil (ferramenta online) que constitui uma base nacional unificada para auxiliar os trabalhos do sistema formado pelos Comitês de Ética em Pesquisa e a Comissão Nacional de Ética em Pesquisa do Conselho Nacional de Saúde (CEP/Conep). Os CEPs são colegiados interdisciplinares e independentes, de relevância pública, de caráter consultivo, deliberativo e educativo, criados para defender os interesses dos participantes da pesquisa em sua integridade e dignidade e para contribuir para o desenvolvimento da pesquisa dentro de padrões éticos (BRASIL, 2012). A Conep é uma instância colegiada, de natureza consultiva, deliberativa, normativa, educativa e independente, vinculada ao Conselho Nacional de Saúde/Ministério da Saúde (MS). A Plataforma Brasil é um passo importante na busca de transparência e agilidade no processo de avaliação envolvendo pesquisas. O objetivo é dar maior segurança ao registro e monitoramento de pesquisas, pois permite o acesso ao número de pesquisas aprovadas ou em tramitação, divididas por região/estados e por área. A sociedade pode ter acesso ainda aos dados de todas as pesquisas aprovadas $^{1}$. O protocolo de pesquisa se refere ao conjunto projeto de pesquisa mais outros documentos exigidos na submissão ao CEP.

Realizou-se uma pesquisa exploratória inicial para levantamento de informações com o intuito de analisar o wayfinding system existente na área de circulação da unidade-caso, ou seja, quais elementos proporcionados pelo ambiente (natural e construído) são utilizados por alunos cegos ou com baixa visão para se orientar em seus deslocamentos. Ainda nessa fase, realizaram-se observações exploratórias iniciais dos alunos.

\footnotetext{
${ }^{1}$ As questões éticas tomaram maior relevância na pesquisa em arquitetura após a Resolução do CNS n. 466/2012 (BRASIL, 2012), que reafirmou a necessidade de submissão do protocolo de pesquisa antes do seu início na Plataforma Brasil (ABATE; KOWALTOWSKI; BERNARDI, 2014).
} 


\section{Técnica de coleta de dados}

Como não foi permitido o acesso a laudos médicos, consequentemente não foi possível o conhecimento das deficiências específicas de cada aluno. No decorrer da pesquisa exploratória inicial, verificou-se a existência da deficiência visual associada a outra(s) deficiências(s), como a intelectual e/ou a física em alguns dos alunos. $\mathrm{Na}$ elaboração de instrumentos de coleta de dados para crianças, em geral, é preciso contemplar aspectos relativos às suas habilidades cognitivas bem como relacionados à experiência, ao conhecimento prévio da temática, ao domínio dos instrumentos a serem utilizados pelo pesquisador, assim como aos recursos disponíveis (financeiros, materiais e humanos), à quantificação do tempo e às restrições impostas pela direção. As pesquisadoras pretendiam aplicar os instrumentos de coleta de dados entrevista e questionário (ABATE, 2011) destinados às crianças e aos docentes, mas a direção autorizou somente as observações dos alunos visando não incomodar a rotina escolar.

A observação permite acesso do pesquisador a aspectos do comportamento humano a respeito dos quais os indivíduos não estão plenamente conscientes, uma vez que o 'comportamento de uma pessoa, o que ela expressa não verbalmente através de gestos intencionais ou não, revela sobre si muito mais do que ela seria capaz de contar' [...], sendo de especial importância para situações em que é limitada a qualidade do depoimento verbal (caso de crianças pequenas, por exemplo). (CORRAZE, 1982, p. 23).

O método observacional é utilizado em situações não estruturadas, fora do controle do experimentador, implicando múltiplos comportamentos e/ou múltiplos atores. Uma vantagem desse método é que, na medida em que o participante da pesquisa não sabe que está sendo observado, "[...] o método torna-se não-invasivo, não provocando reação." (GÜNTHER; ELALI; PINHEIRO, 2008, p. 379). O pré-teste das observações não estruturadas foi realizado antes da primeira e segunda etapas da pesquisa.

\section{Primeira etapa da pesquisa}

$\mathrm{Na}$ primeira etapa da pesquisa (período entre outubro e dezembro de 2012) foram realizadas observações não estruturadas dos alunos com deficiência visual (da pré-escola e do ensino fundamental) para avaliação da orientação durante a circulação no edifício escolar. Foram consideradas nessa etapa todas as classes de préescola e de ensino fundamental (Tabela 1) existentes em 2012 na unidade-caso eleita, e havia uma classe de cada nível (exceto as duas de préescola), todas no período da manhã, totalizando 127 alunos. Desses alunos cerca de $70 \%$ eram cegos e $30 \%$ apresentavam baixa visão, todos com deficiência visual congênita.

Em relação aos procedimentos, utilizou-se a câmera fotográfica, que gera o documento filmográfico (gênero documental integrado por documentos que contêm imagens fixas) para o registro da observação A vantagem de utilizar meios eletrônicos ou mecânicos de registro pelo observador é a possível reprodução das cenas e a análise por mais de um observador, o que permite um consenso. As crianças cegas e com baixa visão não perceberam que estavam sendo observadas e que as fotos estavam sendo realizadas. Para tal, certos cuidados do pesquisador foram adotados, como a utilização de calçados que não emitiam som ao andar, o posicionamento em locais fora da eventual passagem do aluno, a agilidade para sair de trajetos inesperados dos alunos, o uso de máquina fotográfica sem dispositivos que emitissem som ou luz (não uso do flash), entre outros.

Tabela 1 - Distribuição de alunos com deficiência visual por classe em outubro/2012

\begin{tabular}{l|l|c}
\hline \multicolumn{1}{c|}{ Ensino } & Classes & $\mathbf{N}^{\mathbf{0}}$ de alunos \\
\hline \multirow{2}{*}{$\begin{array}{l}\text { Preparatório } \\
\text { pré-escola) }\end{array}$} & $\mathrm{I}$ & 7 \\
\cline { 2 - 3 } & $\mathrm{II}$ & 11 \\
\cline { 2 - 3 } & $1^{\mathbf{0}}$ ano & 13 \\
\cline { 2 - 3 } & $2^{\mathbf{o}}$ ano & 12 \\
\cline { 2 - 3 } & $3^{\mathbf{0}}$ ano & 13 \\
\cline { 2 - 3 } & $4^{\mathbf{o}}$ ano & 11 \\
\cline { 2 - 3 } & $5^{\mathbf{0}}$ ano & 13 \\
\cline { 2 - 3 } & $6^{\mathbf{0}}$ ano & 14 \\
\cline { 2 - 3 } & $7^{\mathbf{0}}$ ano & 11 \\
\cline { 2 - 3 } & $8^{\mathbf{o}}$ ano & 11 \\
\cline { 2 - 3 } & $9^{\mathbf{0}}$ ano & 11 \\
\cline { 2 - 3 } & & $\mathbf{1 2 7}$ (total) \\
\hline
\end{tabular}

Fonte: elaborada pelas autoras com informações da direção. 
O horário permitido pela direção para as observações da circulação dos alunos foi $o$ intervalo, das $9 \mathrm{~h} 55 \mathrm{~min}$ às $10 \mathrm{~h} 20 \mathrm{~min}$ (os alunos de ensino fundamental saíam cerca de 5 minutos depois dos alunos da pré-escola, ou seja, às 10h). As pesquisadoras não foram autorizadas a permanecerem no pátio de recreação, somente na galeria de circulação que une o pátio às salas de aula.

Foram realizadas observações das aulas de O\&M dos alunos do último ano do ensino fundamental (ciclo II) dentro e fora (na rua) da unidade-caso. Hoffmann (1999) define O\&M como um processo amplo e flexível, composto por um conjunto de habilidades motoras, cognitivas, sociais e emocionais e por um grupo de técnicas específicas que possibilitam à pessoa com deficiência visual conhecer, relacionar-se e deslocar-se de forma independente e autônoma nas várias estruturas, nos espaços e nas situações do ambiente.

\section{Etapa intermediária: implementação da sinalização tátil no piso}

Inicialmente, realizou-se o levantamento de medidas com trena de longo alcance da área de circulação para elaboração da implantação da unidade-caso, em escala. Para o apoio nessa medição, foi contratada uma arquiteta externa. $\mathrm{Na}$ especificação da sinalização tátil no piso (modelo, cor, material, textura e tamanho) e definição das diretrizes projetuais (conceitos), além das observações dos alunos, foram realizadas entrevistas com a direção (verificação do projeto pedagógico), professor de O\&M e psicóloga da unidade-caso, psicóloga externa e professor de O\&M de outra instituição que atende crianças com deficiência visual. Foram realizadas ainda entrevistas com três profissionais arquitetos especialistas em acessibilidade que atuam na prefeitura do município de São Paulo, na coordenação de normas técnicas de acessibilidade da ABNT e na instituição pesquisada anteriormente.

O projeto de locação da sinalização tátil no piso foi elaborado com base na NBR 9050 (ABNT, 2004). Realizou-se o levantamento do quantitativo de placas a ser comprado (piso tátil de alerta - Figura 2a, e piso tátil direcional - Figura 2b) e o comparativo entre orçamentos.

O fabricante eleito foi chamado para reunião e vistoria na unidade-caso, com intuito de averiguar se o piso existente estaria apto a receber a sinalização tátil.

Em relação ao piso tátil, foi realizada ainda a compra do material (cola e piso), a contratação da mão de obra para execução da instalação, e o acompanhamento da entrega, da instalação (em 3 datas distintas) e da medição.

\section{Segunda etapa da pesquisa}

$\mathrm{Na}$ segunda etapa da pesquisa (período entre agosto e setembro de 2014), foram realizadas observações não estruturadas dos alunos (da préescola e do ensino fundamental) com deficiência visual para avaliação da orientação durante a circulação no edifício escolar após a implantação da sinalização tátil no piso. Foram consideradas nesta pesquisa todas as classes de pré-escola e de ensino fundamental (Tabela 2) existentes em 2014 na unidade-caso eleita, e havia uma classe de cada nível (exceto as duas de pré-escola), todas no período da manhã, totalizando 135 alunos. Destes alunos cerca de $70 \%$ eram cegos e $30 \%$ apresentavam baixa visão, todos com deficiência visual congênita.

Figura 2 - Sinalização tátil de (a) alerta e (b) tátil direcional

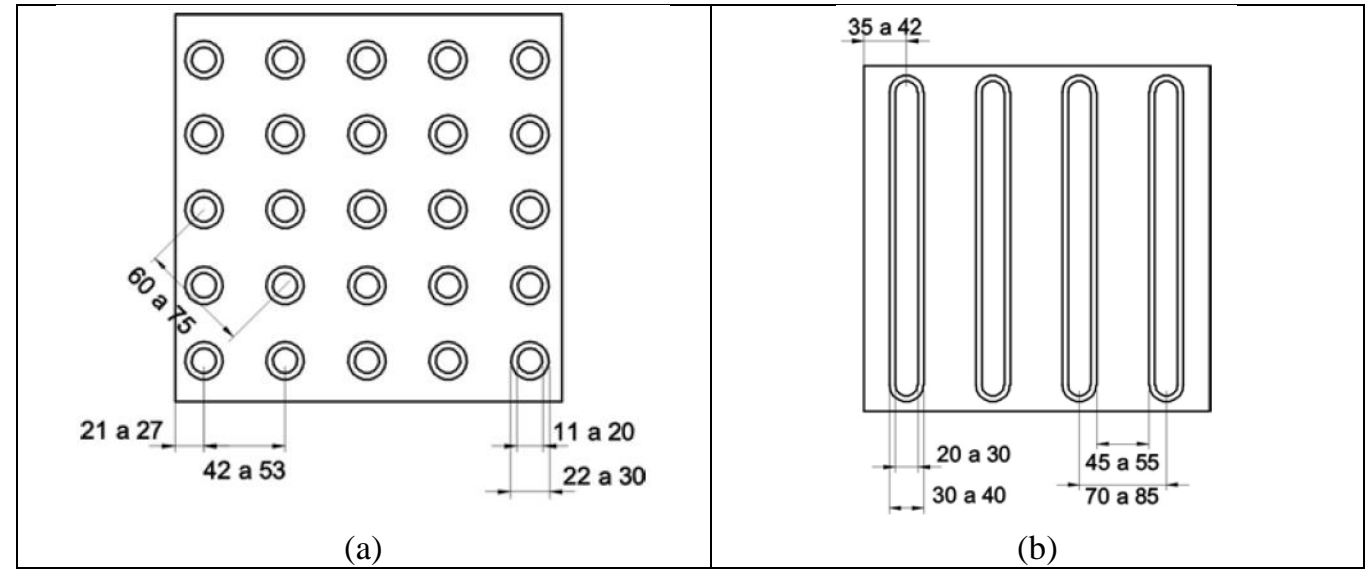

Fonte: NBR 9050 (ABNT, 2004).

58 Abate, T. P.; Kowaltowski, D. C. C. K. 
Tabela 2 - Distribuição de alunos com deficiência visual por classe em agosto/2014

\begin{tabular}{c|l|c}
\hline Ensino & Classes & $\mathbf{N}^{\mathbf{0}}$ de alunos \\
\hline \multirow{4}{*}{$\begin{array}{c}\text { Preparatório } \\
\text { (pré-escola) }\end{array}$} & $\mathrm{I}$ & 9 \\
\cline { 2 - 3 } & II & 12 \\
\hline \multirow{5}{*}{ Fundamental } & $1^{\mathbf{o}}$ ano & 12 \\
\cline { 2 - 3 } & $2^{\mathbf{o}}$ ano & 12 \\
\cline { 2 - 3 } & $3^{\mathbf{o}}$ ano & 12 \\
\cline { 2 - 3 } & $4^{\mathbf{o}}$ ano & 13 \\
\cline { 2 - 3 } & $5^{\mathbf{o}}$ ano & 12 \\
\cline { 2 - 3 } & $6^{\mathbf{o}}$ ano & 13 \\
\cline { 2 - 3 } & $7^{\mathbf{o}}$ ano & 15 \\
\cline { 2 - 3 } & $8^{\mathbf{o}}$ ano & 15 \\
\cline { 2 - 3 } & $9^{\mathbf{o}}$ ano & 10 \\
\hline
\end{tabular}

Fonte: elaborada pelas autoras com informações da direção.

Foram adotados os mesmos procedimentos da primeira etapa de pesquisa descritos anteriormente.

\section{Resultados}

A pesquisa exploratória inicial ofereceu um panorama do wayfinding system existente na área de circulação da unidade caso que é composta de uma galeria semiaberta para um jardim interno (Figura 3). Segundo a direção, vários elementos contribuem para a orientabilidade dos alunos com deficiência visual, como a existência de plano inclinado propiciado pela topografia do terreno (Figura 3c), incidência de vento, tipologias de piso (Figuras 4a a 4c), focos de geração de ruído (gaiolas de $\operatorname{araras}^{2}$ e fonte de água) e de odor (paisagismo em função das flores das azaleias e roseiras), percepção de cheios e vazios em função da galeria semiaberta (tipologia de projeto), paredes, rodapés, corrimãos de escadas, entre outros.

Em relação aos tipos de pisos existentes na galeria que circunda o jardim interno, verifica-se a existência do revestimento cerâmico esmaltado (Figura 4a) na galeria coberta que dá acesso ao bloco do pátio coberto. O piso pré-moldado de cimento e brita (Figura 4 b) foi colocado somente na via existente interna ao lote (ver Figura 15). O piso de lajota cerâmica desgastada pelo uso (Figura 4c) se encontra presente na maior parte da galeria de circulação. Os vários tipos de superfícies dos pisos possibilitam o reconhecimento tátil pelos alunos e os auxiliam na localização espacial.

A unidade-caso dispõe de um mapa tátil (Figura 5a), porém seu tamanho e altura não são compatíveis (muito grande e alto, respectivamente) com o alcance frontal manual (Figura $6 \mathrm{~b}, \mathrm{c}$ ) das crianças de pré-escola e do ensino fundamental $1^{\circ}$ ciclo (testado em pesquisa anterior de Abate (2011)).

Sabe-se que a orientação no espaço depende principalmente da percepção visual e da audição, mas também do projeto arquitetônico desse espaço, seja ele urbano ou do interior de edificações. Esse projeto, por sua vez, apresenta-se por meio da clareza do seu sistema de circulação e dos marcos presentes.

A sinalização gráfica com o uso de placas é incipiente na unidade-caso. Existem poucas placas em bronze sem legibilidade (falta de contraste) para o aluno com baixa visão e sem o Braille para o aluno cego. Foram realizados projetos de placas de sinalização na unidade-caso por alunos de Design Gráfico (Figuras 6 e 7) sob orientação das autoras, que ainda não haviam sido implementados em função do custo.

Observou-se que os alunos (cerca de $70 \%$ cegos e $30 \%$ com baixa visão) não utilizavam a bengala de rastreamento dentro da unidade-caso. Quando o aluno ingressa na escola, é realizado um trabalho de reconhecimento dos percursos e do ambiente. A disciplina de O\&M, que orienta o uso da bengala, entre outros, é oferecida ao final do ensino fundamental.

\section{Primeira etapa da pesquisa}

As observações da circulação dos alunos de préescola e ensino fundamental no trajeto permitido pela direção, sala de aula-pátio de recreação e vice-versa foram realizadas com duração de cerca de 40 minutos cada observação no período de outubro a dezembro de 2012.

${ }^{2}$ Recomenda-se a retirada das araras em função das entrevistas realizadas com as crianças (ABATE, 2011). 
Figura 3 - Galeria de circulação da unidade-caso

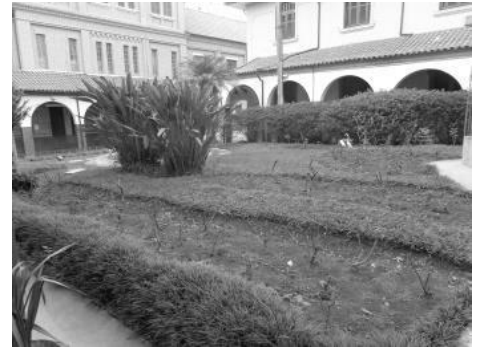

(a)

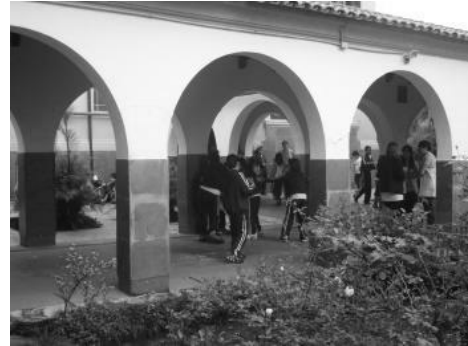

(b)

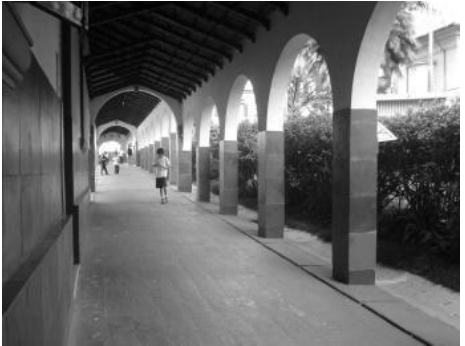

(c)

Figura 4 - Tipos de piso existentes na galeria de circulação

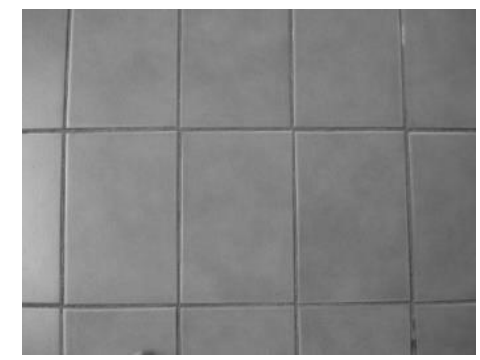

(a)

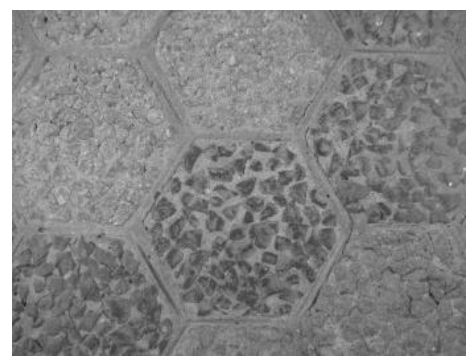

(b)

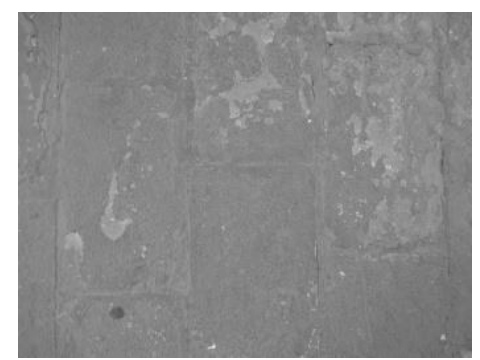

(c)

Figura 5 - Aplicação de entrevista com o uso de mapa tátil

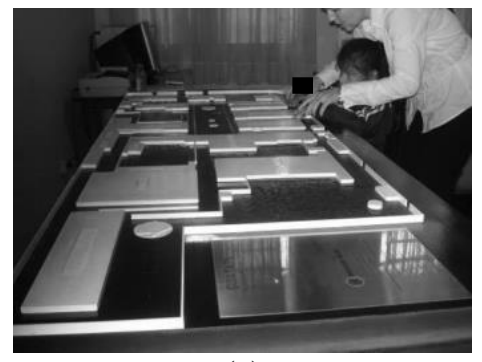

(a)

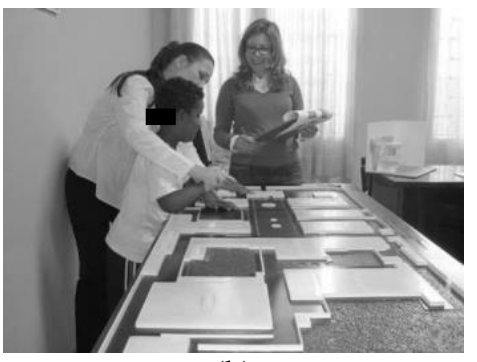

(b)

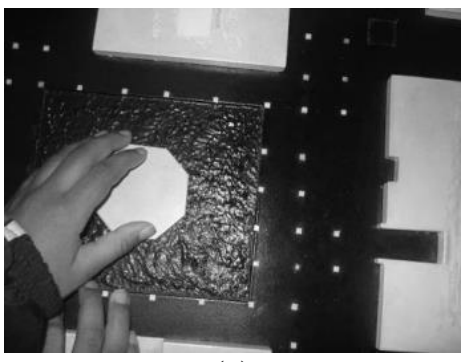

(c)

Fonte: Abate (2011).

Figura 6 - Estudo de sinalização interna

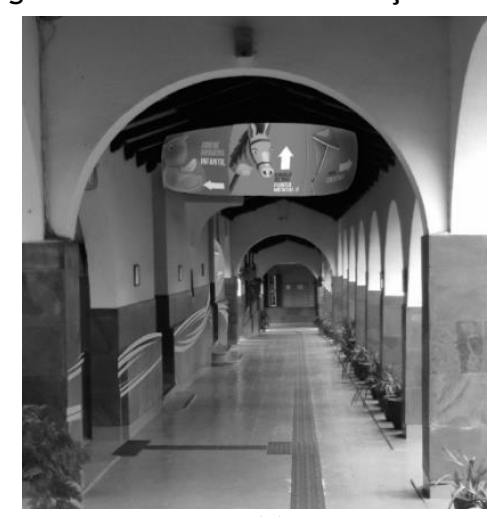

(a)

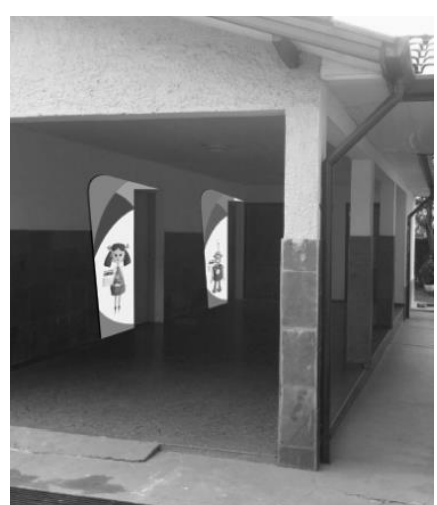

(b)

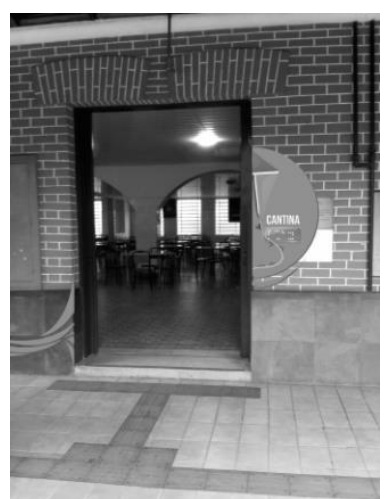

(c)

Fonte: Rocha et al. (2014). 
Figura 7 - Estudo de sinalização externa

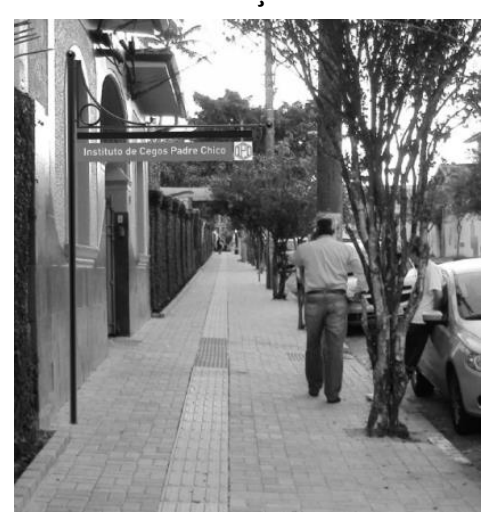

(a)

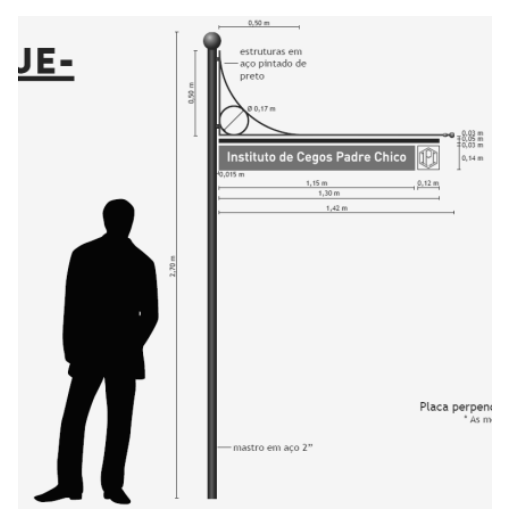

(b)

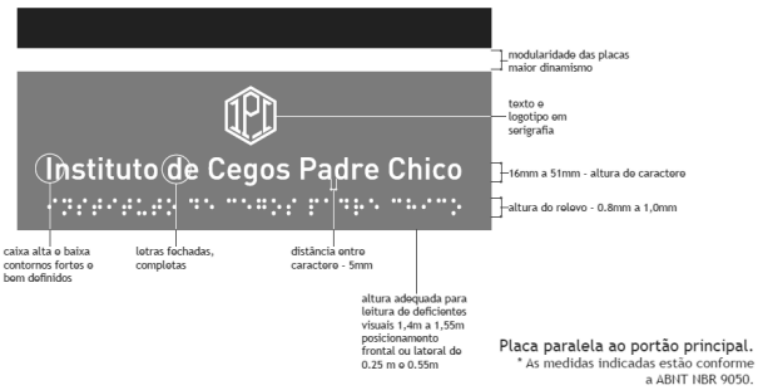

(c)

Fonte: Holovatuk (2013).

Uma das pesquisadoras se posicionou na galeria de circulação à espera da saída dos alunos das classes. As duas classes de pré-escola existentes foram as primeiras a sair da sala de aula e se dirigir ao pátio de recreação, uma seguida da outra, acompanhadas pelas respectivas docentes e uma assistente que auxiliava uma das turmas (Figura 8a). Em seguida, todos os alunos de ensino fundamental deixaram as salas em direção ao pátio de recreação. Observouse a alta densidade de alunos na galeria (Figura $8 b$ ), não havendo sentido obrigatório de direção. Verificou-se que não há escalonamento no horário de saída para o intervalo das crianças do ensino fundamental, o que ocasionou um grande fluxo de alunos utilizando ao mesmo tempo os corredores de circulação.

Verificou-se que apenas os alunos de pré-escola recebem auxílio na locomoção em função de ainda não dominarem o ambiente, isso também acontece com outros alunos que têm deficiência física, além da visual. Em relação ao agrupamento na locomoção dos alunos (Figura 9), observou-se que o aluno se locomove sozinho (a), em duplas (b), em trios (c) ou em grupos de mais alunos (d), compostos somente por alunos cegos ou por aluno(s) cego(s) e com baixa visão.
Docentes recomendam grupos de no máximo três alunos para evitar a obstrução da circulação e trombadas. Verificou-se nos agrupamentos que alguns alunos cegos eram guiados por outro com baixa visão, o que pode indicar algum grau de dependência em alguns casos, porém não se pode confundir com o comportamento típico dessa faixa etária, caracterizado pela aglutinação.

Em relação aos níveis de dificuldade na orientação espacial de alunos com deficiência visual (com e sem o auxílio de um vidente), verificou-se que a maioria dos alunos de ensino fundamental conseguiu realizar o percurso da sala de aula ao pátio de recreação e vice-versa sem dificuldade (Figura 10).

Alguns alunos dos primeiros anos do ensino fundamental apresentaram maior dificuldade na orientação espacial (Figuras 11a a 11d). Essa dificuldade foi observada em função do maior tempo dispensado no percurso em comparação com os demais alunos.

Observou-se a não existência de regras (mãos de direção) de uso na circulação do espaço escolar da unidade-caso. 
Figura 8 - Classe de pré-escola (a) e classes de ensino fundamental (b)

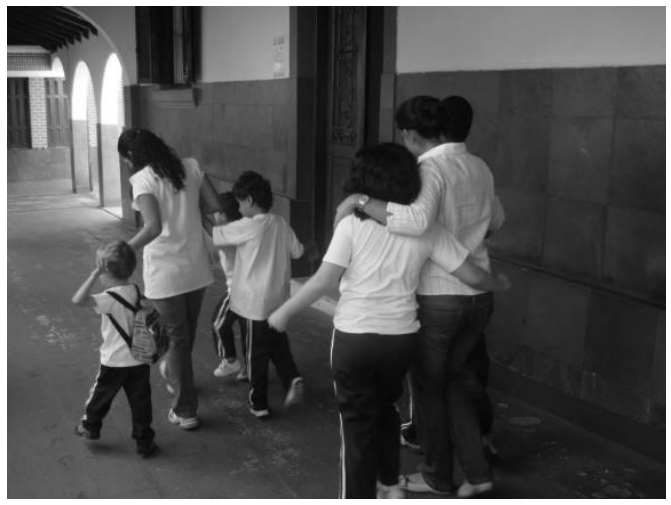

(a)

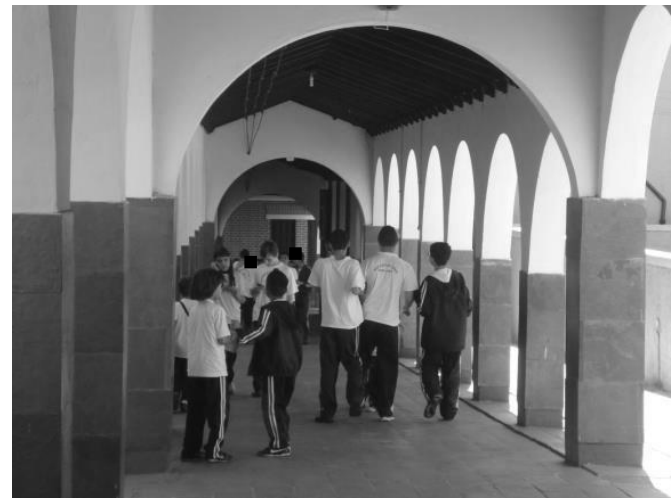

(b)

Figura 9 - Agrupamentos na locomoção dos alunos com deficiência visual

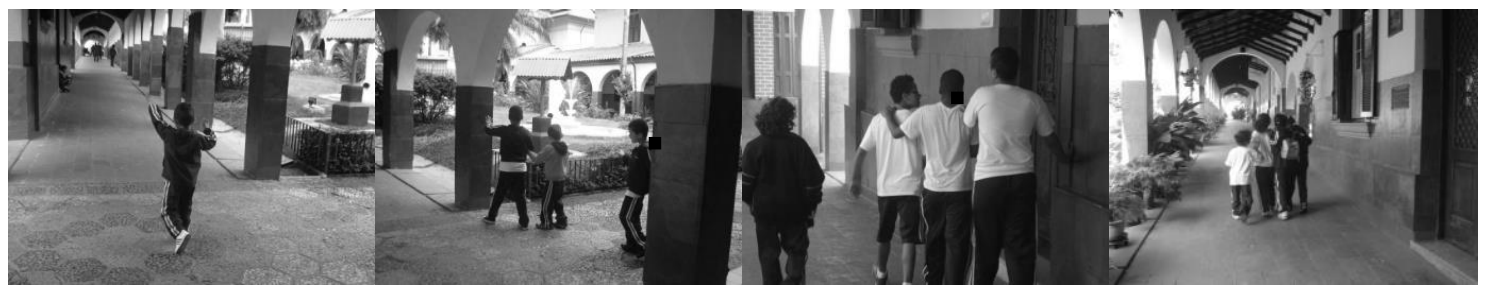

(a)

(b)

(c)

(d)

Figura 10 - Alunos com deficiência visual correm (a) e andam (b) sem dificuldade

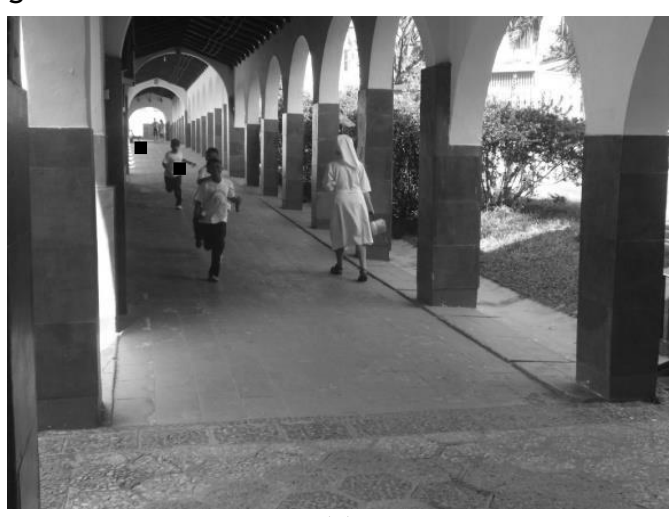

(a)

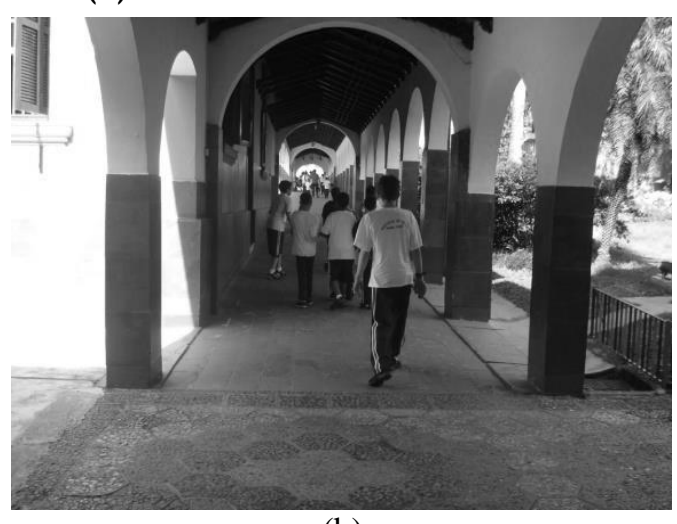

(b) 
Figura 11 - 0 aluno com baixa visão posiciona a ponta do pé na guia (a) e tateia os pilares (b) durante seu percurso; outro aluno se mantém imóvel por vários minutos até que alguém o acompanhe no trajeto (c); e outro aluno caminha devagar e com cautela e mantém as mãos à frente do corpo (d)

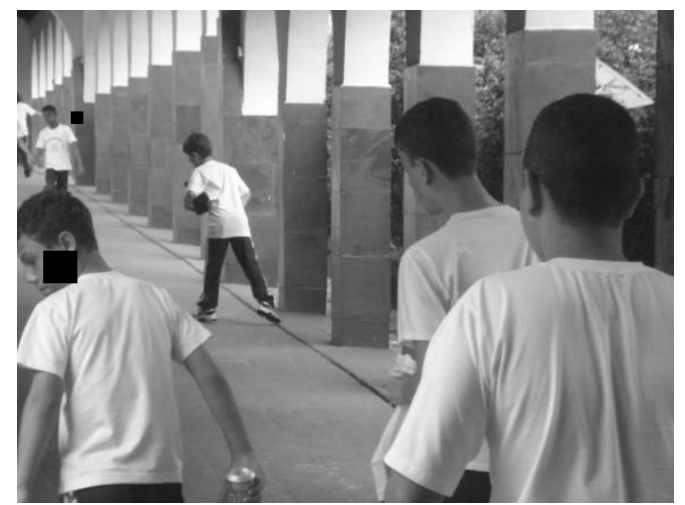

(a)

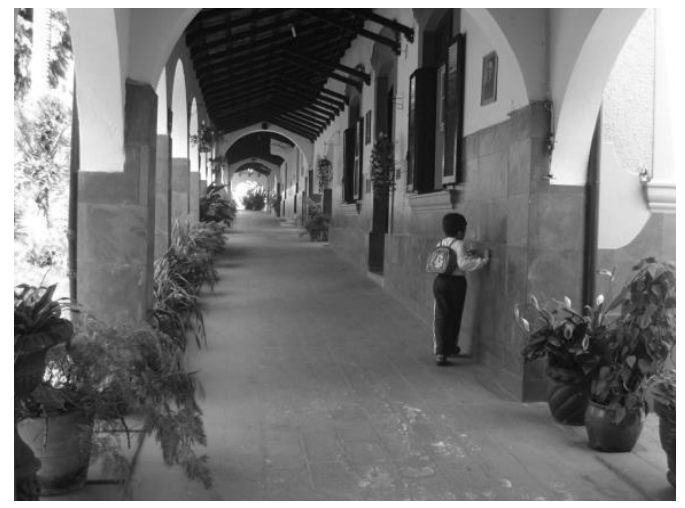

(c)

\section{Etapa intermediária: implementação da sinalização tátil no piso}

A especificação da sinalização tátil no piso se encontra descrita a seguir:

(a) placas em poliéster coladas no piso cerâmico existente;

(b) tamanho de $25 \mathrm{~cm} \times 25 \mathrm{~cm}$;

(c) cor preta em função do contraste de luminância em relação ao piso adjacente, para ser percebida por pessoas com baixa visão; e

(d) textura levemente rugosa antiderrapante de relevo contrastante em relação ao piso adjacente, com outra textura ${ }^{3}$ em forma de pequenos pontos para ser claramente percebida (Figura 12) por pessoas com deficiência visual que se utilizam da técnica de bengala de rastreamento.

Os relevos táteis instalados diretamente no piso (parafusados) não puderam ser adotados em função da porosidade da cerâmica existente. As autoras realizaram uma ampla pesquisa de tipologias de

${ }^{3}$ Sem considerar o relevo característico da sinalização tátil de alerta e tátil direcional (ver Figura 2).

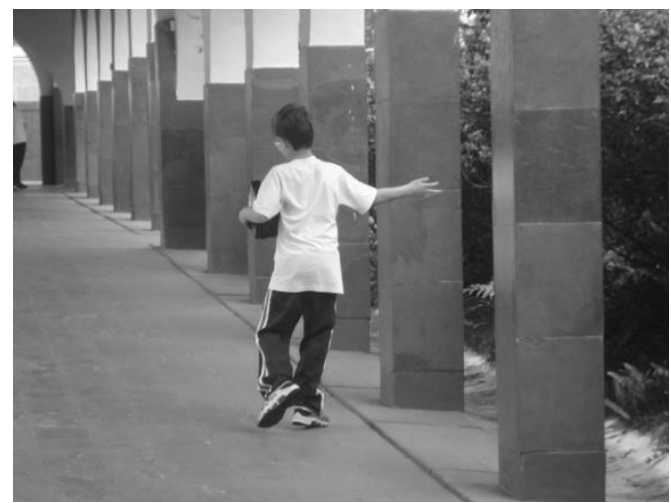

(b)

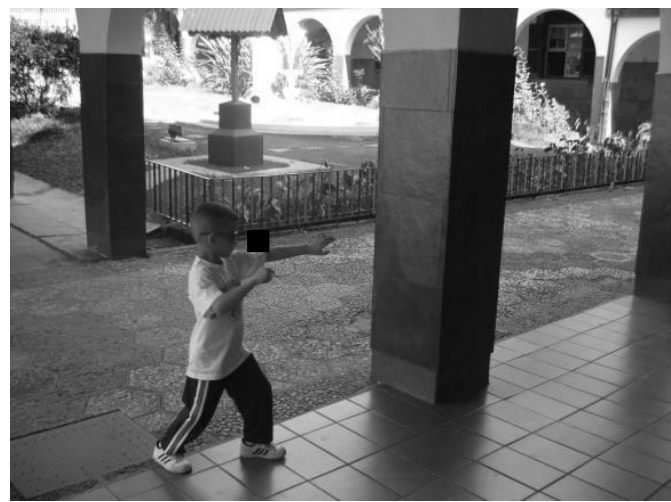

(d)

sinalização tátil de piso disponíveis no mercado. Um único fabricante atendia a todos os requisitos descritos na especificação acima.

Em relação às diretrizes projetuais, definiu-se como conceito aliar o projeto pedagógico ao projeto de sinalização tátil no piso. Dessa forma, o projeto deveria atender, em especial, a disciplina de O\&M.

A faixa de piso tátil direcional não foi colocada no meio dos corredores de circulação principal, visando permitir o treino do aluno com a bengala de rastreamento em área livre de sinalização tátil de piso. Buscou-se maior afastamento da rota de saída das portas existentes, adotando-se a distância mínima de 1,00 m entre a borda da sinalização tátil direcional no piso e as paredes, os pilares ou outros objetos/obstáculos, conforme a Figura 13.

A distância mínima citada acima está contida no texto base da norma da ABNT de Sinalização tátil no piso: diretrizes para elaboração de projetos, extraído durante o período de consulta pública.

Recomendou-se que na via existente interna ao lote não trafegasse nenhum tipo de veículo. Essa via seria mantida e sinalizada para o treino de travessia pelos alunos com deficiência visual nas 
aulas de O\&M (Figura 14). O piso rugoso de mosaico se alterna para o liso de cerâmica, onde se encontra o início da rota do piso tátil. À direita do aluno, localiza-se uma fonte de água (emissão de ruído), coincidindo com o início da sinalização tátil no piso.

O projeto inicial previa a colocação do piso de sinalização tátil na maioria das entradas dos edifícios ao redor do jardim interno. Após análise realizada pela equipe multidisciplinar, buscou-se não utilizar a sinalização tátil no piso de forma excessiva, visando não atrapalhar a orientação dos alunos com deficiência visual, inclusive facilitando a rota de fuga (segurança contra incêndio). Os projetos de acessibilidade física, segurança contra incêndio e segurança patrimonial devem ser compatibilizados (ONO; MOREIRA, 2010). Dessa forma, eliminou-se a sinalização de algumas portas de menos uso pelos alunos (marcação X na Figura 15 a seguir). Segundo Dischinger e Bins-Ely (2010), a percepção pode ser potencializada por meio de elementos ou informações contidas no ambiente, ou pode ser prejudicada caso sejam utilizados em excesso.

\section{Figura 12 - Detalhes das placas de piso tátil não assentado}

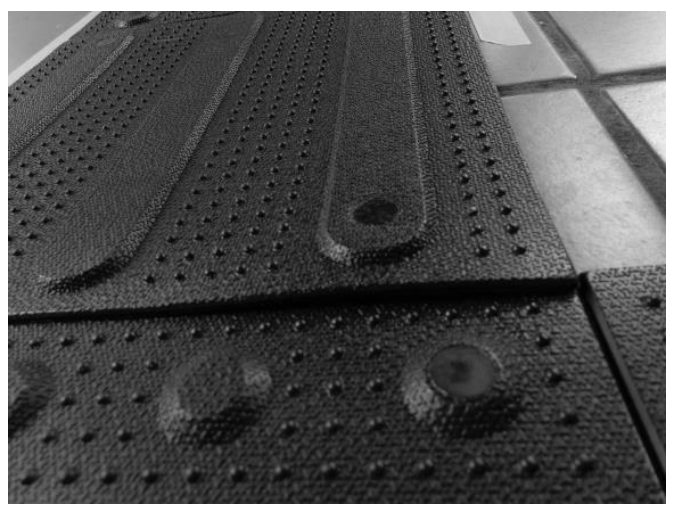

Figura 13 - Distância mínima entre a faixa de piso tátil direcional e obstáculos

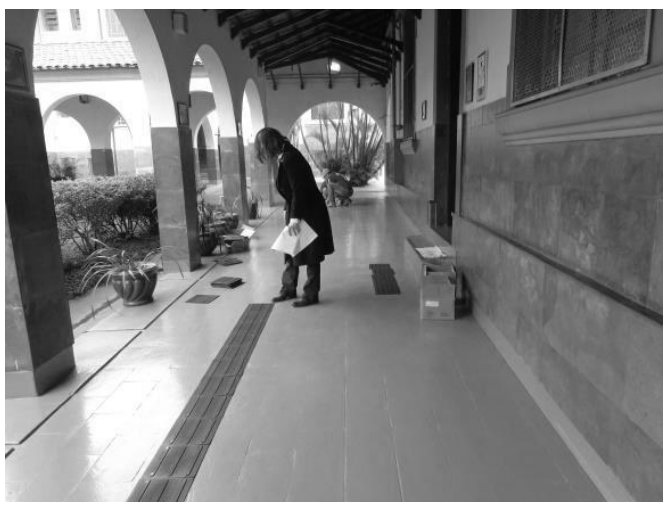

Figura 14 - Via interna do lote

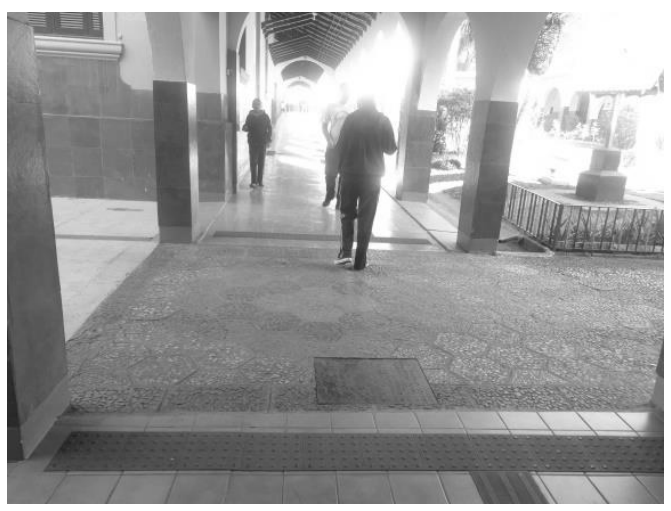

64 Abate, T. P.; Kowaltowski, D. C. C. K. 
Figura 15 - Projeto de locação do piso tátil corrigir

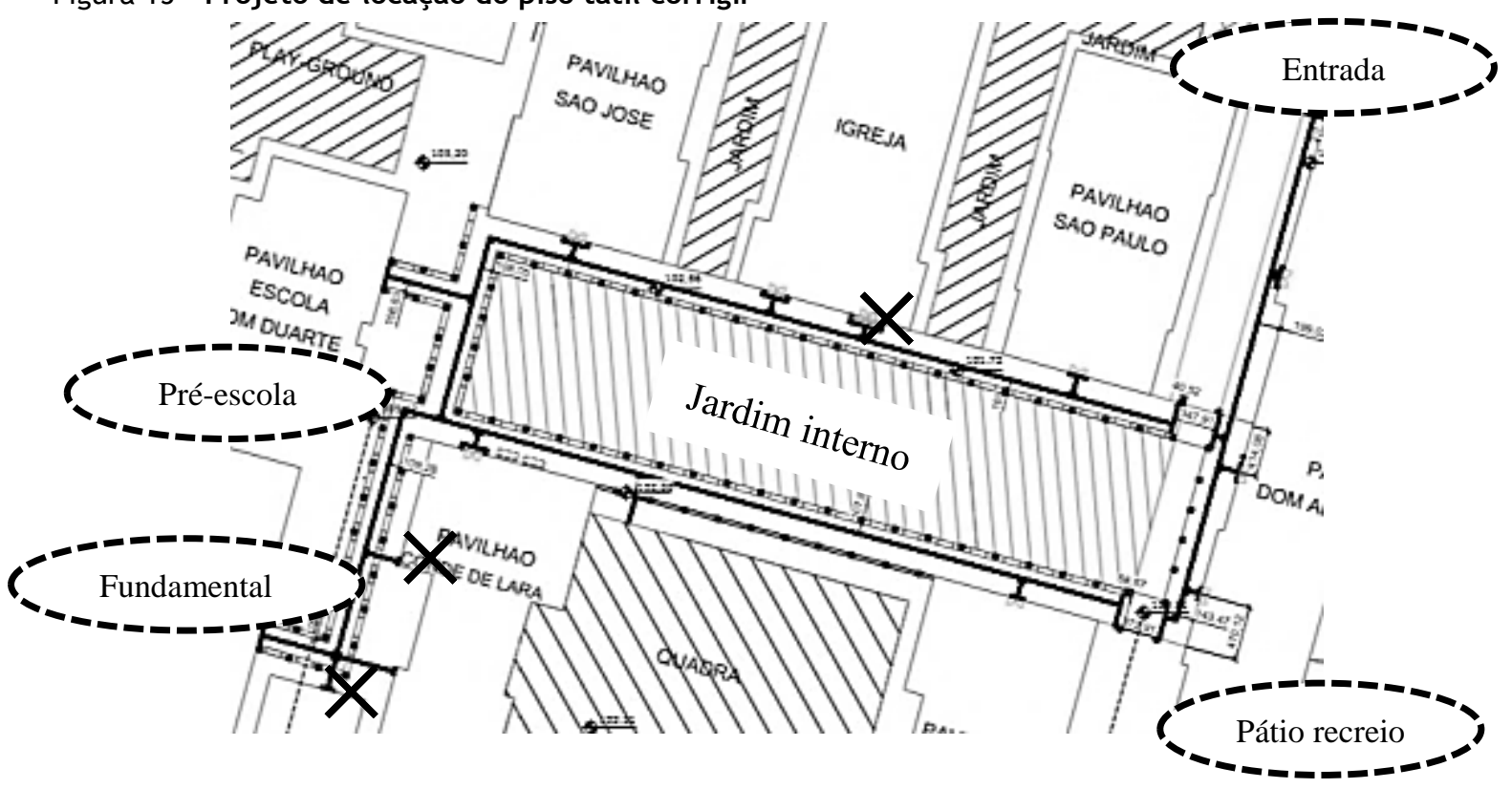

Figura 16 - Projeto de locação do piso tátil com imagens

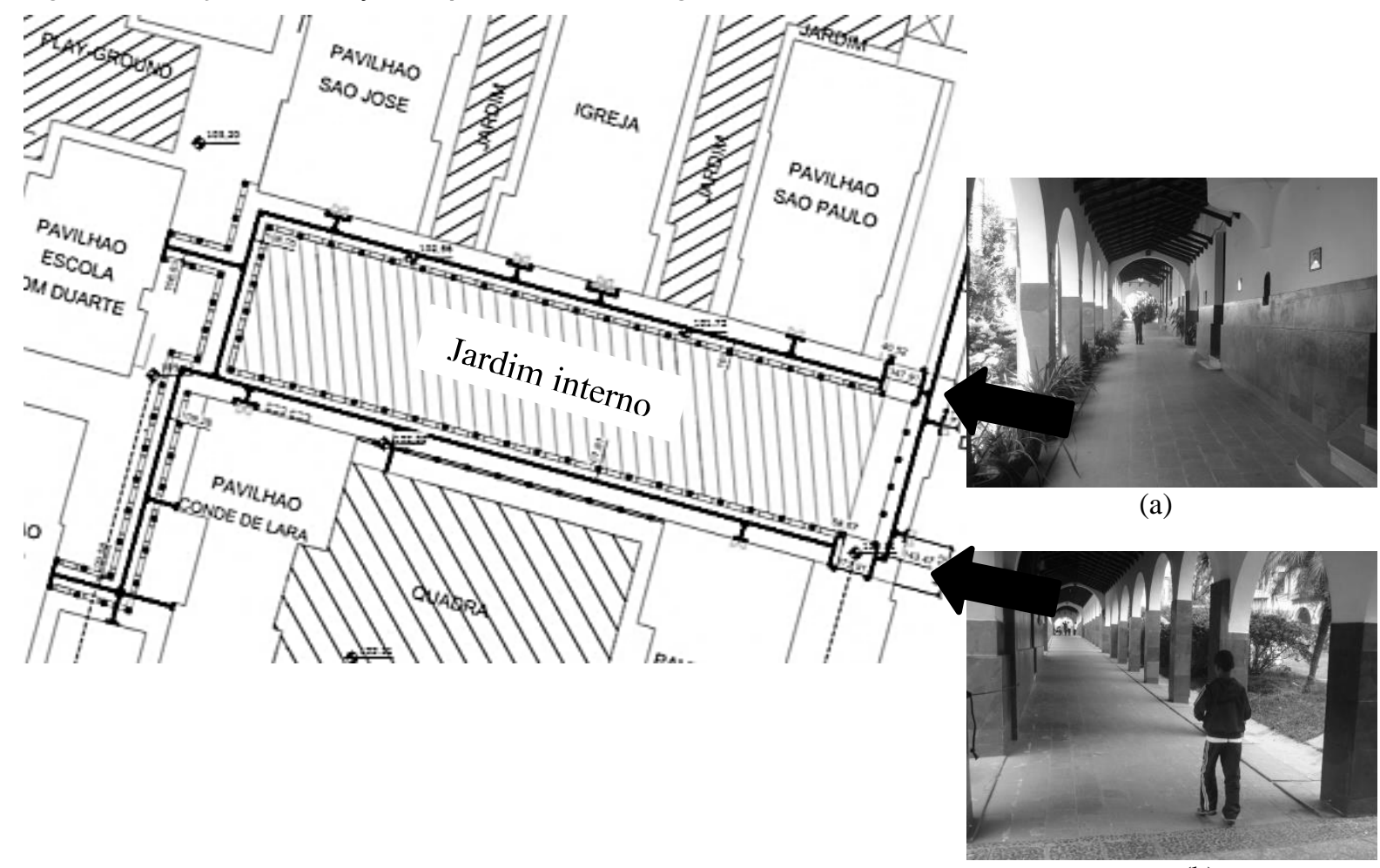

(b)

O projeto de sinalização de piso abrangeu o trajeto da entrada da unidade-caso, porém ele não foi executado ainda em função de necessidade de obras de alargamento de calçada interna e remanejamento da rede de captação de água pluvial.

A Figura 16 a seguir fornece mais informações sobre o projeto do piso tátil.
A Figura 16a mostra a rota habitualmente usada pelos alunos ao iniciarem as aulas pela manhã. Mesmo não havendo regras de uso das rotas, percebeu-se por meio das observações que no horário de intervalo os alunos utilizavam a rota relativa à Figura $16 \mathrm{~b}$ em função de sua proximidade com o refeitório. 
O projeto de sinalização tátil no piso contemplou a adoção de mãos de direção na galeria principal (Figura 17) em função da alta densidade de alunos com deficiêcia visual na unidade-caso. A eleição das mãos de direção seguiu o critério de proximidade com a entrada ao lote e ao refeitório, no início e no intervalo da aula, respectivamente.

A sinalização tátil de alerta no piso foi utilizada para informar ao aluno com deficiência visual sobre a existência de desníveis, informar as mudanças de direção ou opções de percursos, indicar início e o término de degraus e escadas, bem como indicar as travessias. A sinalização tátil direcional no piso foi instalada no sentido do deslocamento dos alunos, pois eles não utilizavam a bengala direcional e não conseguiam identificar a linha-guia existente no piso. Essa sinalização indica os caminhos preferenciais de circulação. (ABNT, 2004).

Detectou-se que o piso existente necessitaria de reforma para estar apto a receber o piso tátil, pois alguns trechos da superfície da cerâmica começaram a descascar. Essa reforma atrasou o cronograma inicial da pesquisa. A superfície da cerâmica existente foi lixada e recebeu tinta plástica de cor alaranjada.

Após a reforma, acompanhou-se a colocação da sinalização tátil sobre o piso em 3 dias alternados (3 finais de semana), visando não atrapalhar a rotina dos alunos (Figura 18). Salienta-se que o modo de colocação não é foco deste estudo, pois cada fabricante utiliza sua própria técnica.

Figura 17 - A adoção de mãos de direção na galeria principal

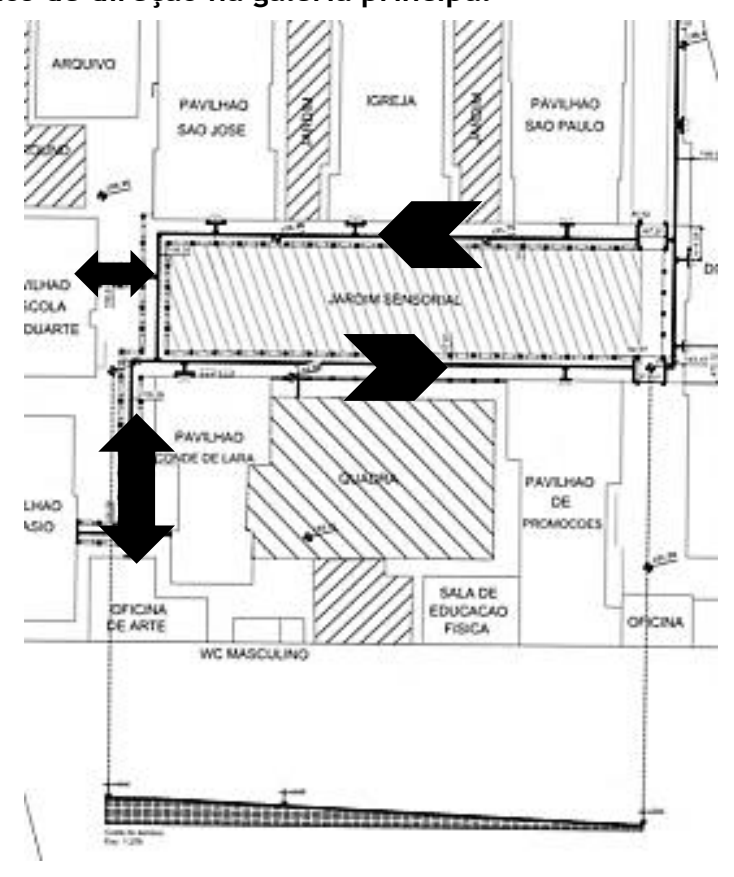

Figura 18 - Colocadores da empresa Andaluz

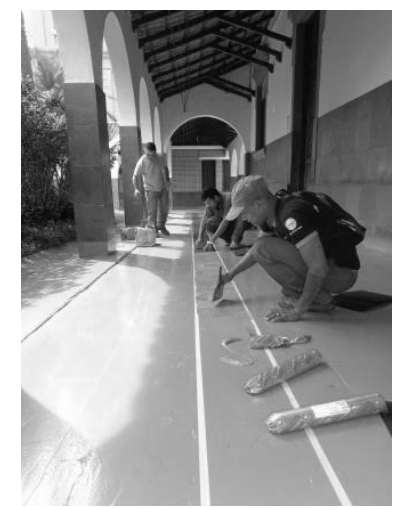

(a)

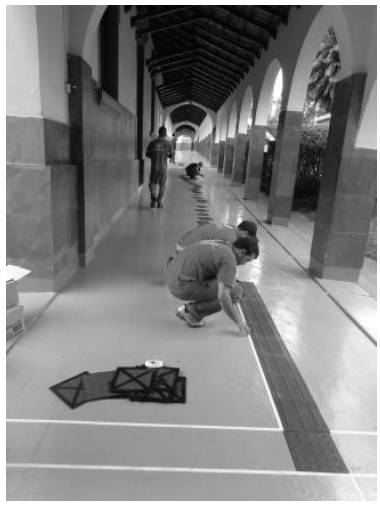

(b)

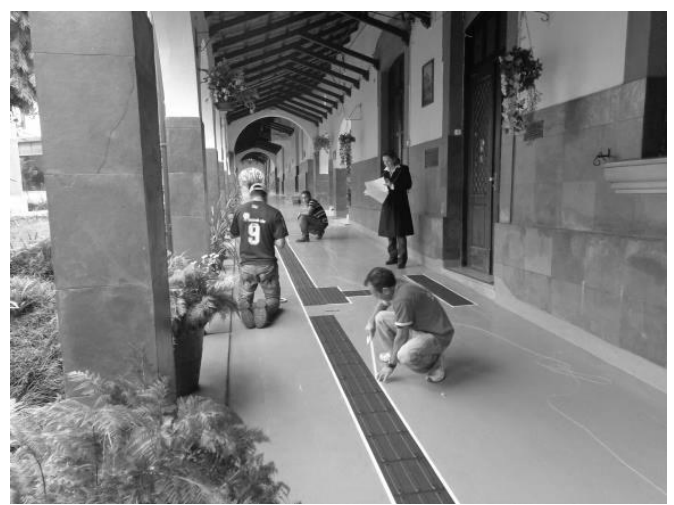

(c)

66 Abate, T. P.; Kowaltowski, D. C. C. K. 
Essa colocação em etapas propiciou observações do impacto do piso no ambiente, pois havia preocupação de os alunos com deficiência visual tropeçarem nele (alguns arrastam os pés e outros correm muito), bem como dos alunos com deficiência física associada à visual apresentarem dificuldade no transpasse dos equipamentos de tecnologia assistiva (Figura 19).

\section{Segunda etapa da pesquisa}

As observações da circulação dos mesmos alunos de pré-escola e ensino fundamental (e alguns novos) no mesmo trajeto da primeira etapa da pesquisa foram realizadas com duração de cerca de 60 minutos cada uma no período de agosto a setembro de 2014.

Percebeu-se que os alunos agrupados eram guiados, geralmente, por um aluno com baixa visão e não utilizavam a sinalização tátil no piso como orientação direta (Figura 20a). Alguns alunos com baixa visão utilizavam essa sinalização como guia lateral e não pisavam (ou tateavam com os pés), apenas a tangenciavam (Figura 20b). Outros alunos antigos na escola continuavam a utilizar as paredes como guia de orientação (Figura 20c - mesmo aluno da Figura 11a e 11b. As dimensões corporais da criança permitem que, durante a sua marcha, ambos os pés se mantenham sobre a faixa da sinalização tátil no piso (Figura 20d).

Verificou-se novamente que não há escalonamento no horário de saída para o intervalo das crianças do ensino fundamental, gerando um grande fluxo de alunos que utilizam ao mesmo tempo os corredores de circulação.

O aluno cego da Figura 21 a seguir realiza o trajeto do pátio de recreação para a sala de aula devagar com algum grau de dificuldade em relação à orientabilidade em função de ser novo na escola. $\mathrm{O}$ aluno foi posicionado no início do trajeto por uma assistente e iniciou a sua navegação de forma lenta, posicionando os braços à frente do corpo. $\mathrm{O}$ aluno sobe a galeria (plano inclinado) tateando com um dos pés o piso tátil direcional durante todo o seu trajeto (Figura 21a). O sentido cinestésico do aluno, entre outros, o auxilia na orientação de seu trajeto, pois quando o piso se nivela ocorre a flexão de $90^{\circ}$ à esquerda no trajeto (Figura 21b) indicada pelo piso tátil de alerta. Nesse ponto o aluno para e realiza a varredura com um dos pés por alguns segundos (Figura 21c) até encontrar a nova direção de sua rota. Percebe-se a necessidade do uso da bengala de rastreamento pelo aluno para realizar essa tarefa de varredura. Esse aluno se apropriou totalmente da sinalização tátil no piso como importante elemento pertencente ao wayfinding system.

\section{Conclusões}

Este artigo buscou analisar a orientação espacial dos alunos com deficiência visual em escola de educação especial localizada na cidade de São Paulo antes (primeira etapa da pesquisa) e após (segunda etapa da pesquisa) a implantação da sinalização tátil no piso, importante elemento do sistema chamado wayfinding.

\section{Primeira etapa da pesquisa}

O fato de as crianças não enxergarem ou enxergarem de forma reduzida tornou a presença das pesquisadoras não evidente, o que favoreceu o comportamento natural delas no decorrer das observações.

Figura 19 - Alunos com deficiência visual e física que utilizam andador (a) e muletas (b)

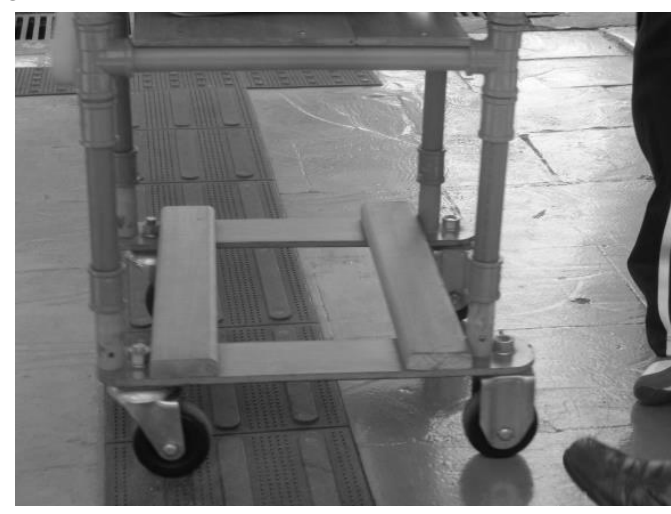

(a)

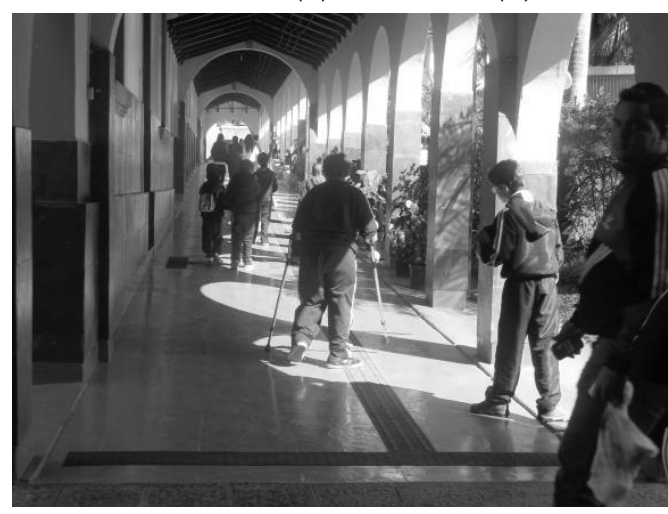

(b) 
Figura 20 - Locomoção dos alunos do ensino fundamental

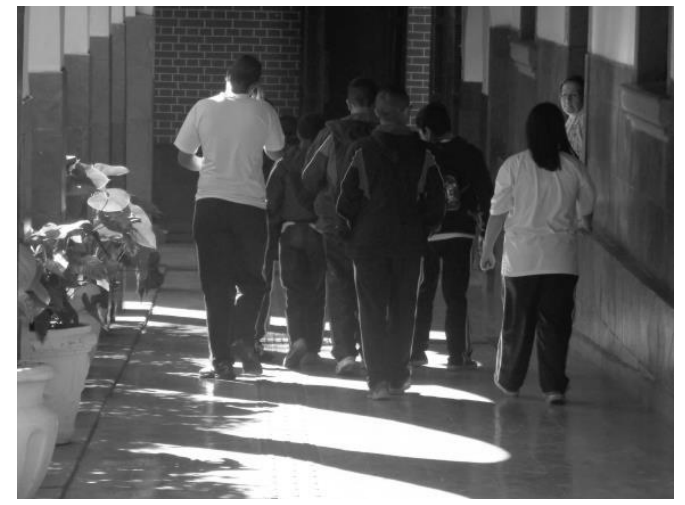

(a)

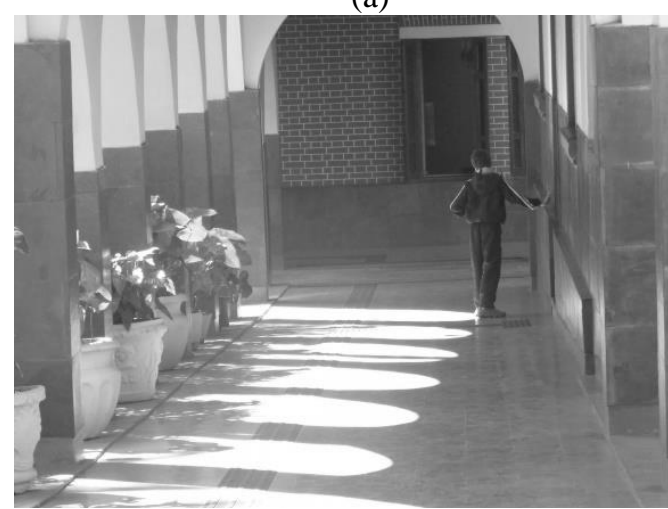

(c)

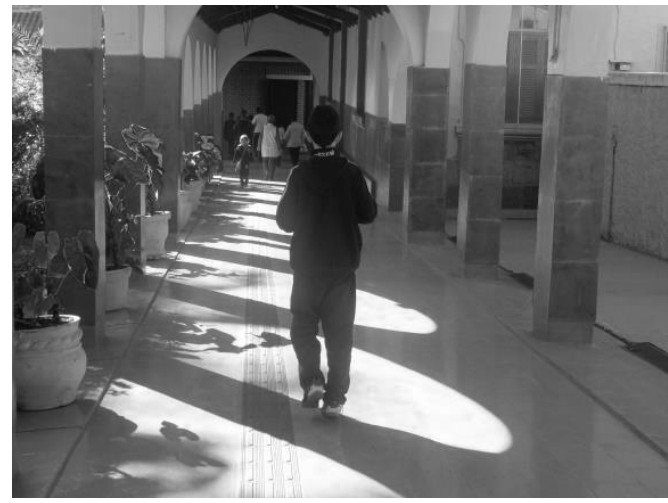

(b)

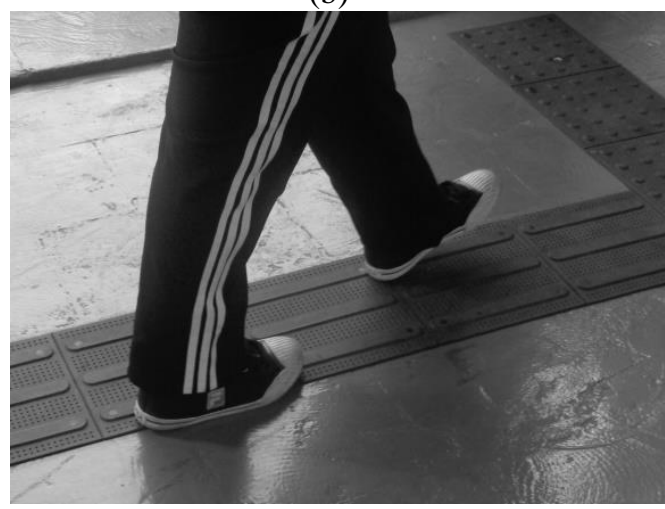

(d)

Figura 21 - Trajeto de aluno cego que realiza a varredura com um dos pés

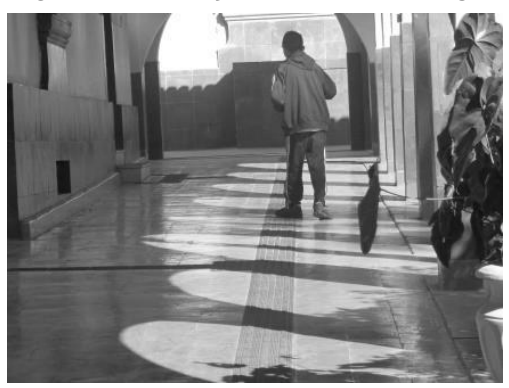

(a)

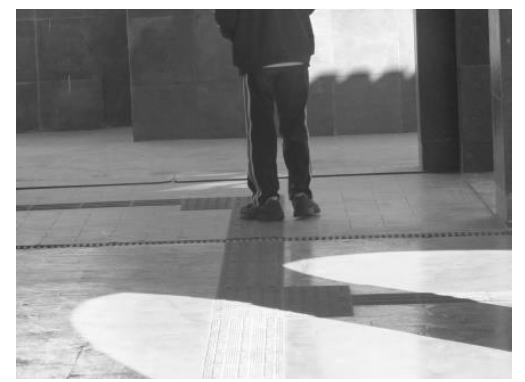

(b)

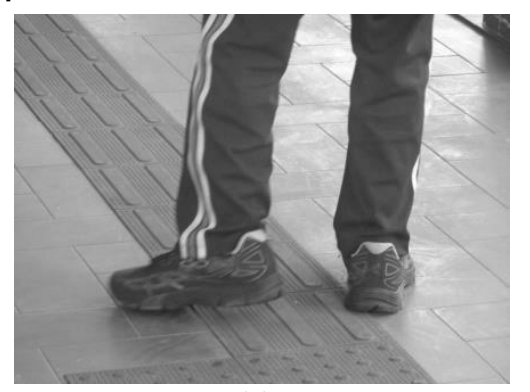

(c)
Constatou-se que a inexistência da sinalização tátil no piso na área de circulação escolar gera dificuldades na orientação dos alunos com deficiência visual da pré-escola, do primeiro ano de ensino fundamental e dos alunos novos na instituição. Cada um desses alunos desenvolve um recurso para atingir o mesmo objetivo (realizar o percurso da sala de aula ao pátio de recreação e vice-versa). De acordo com a direção, os alunos mais antigos se orientam com facilidade nos corredores de circulação em função do referencial oferecido pelos elementos do wayfinding system existente, como o plano inclinado propiciado pela topografia do terreno (ver Figura 3c), incidência de vento, tipologias de piso (ver Figura $4 \mathrm{a}-\mathrm{c}$ ), focos de geração de ruído (gaiolas de araras e fonte de água) e de odor (paisagismo em função das flores das azaleias e roseiras), percepção de cheios e vazios em função da galeria semiaberta (tipologia de projeto), paredes, rodapés, corrimãos de escadas, entre outros.

\section{Segunda etapa da pesquisa}

$\mathrm{O}$ projeto de sinalização tátil no piso atendeu as diretrizes do projeto pedagógico, em especial a disciplina de O\&M. Verificou-se que a implantação da sinalização tátil no piso nas áreas de circulação auxilia a orientação dos alunos de pré-escola, do primeiro ano de ensino fundamental e dos alunos novos na instituição (ver Figura 21). 
A maioria dos alunos antigos na instituição continua a se orientar com facilidade nos corredores de circulação, guiando-se pelos elementos do wayfinding system existente, ou no caso de duplas ou grupos, pelo aluno vidente.

Constatou-se que a implantação da sinalização tátil no piso nas áreas de circulação de alunos com deficiência visual novos e antigos na instituição requer familiarização com o uso, iniciada por meio de treinamento de O\&M; disponibilização e aprendizado de uso concomitante do mapa tátil; adoção da bengala de rastreamento; escalonamento dos horários de intervalo das diferentes classes; definição de mãos de direção; segurança no trajeto; e monitoramento.

Acredita-se que a falta de treinamento do uso da sinalização tátil no piso gerou menor uso dessa sinalização pelos alunos antigos. $\mathrm{Na}$ época da pesquisa um novo professor de orientabilidade ingressou na unidade caso, e suas prioridades iniciais se encontravam em outra esfera.

Destaca-se que os alunos cegos e com baixa visão não devem ser induzidos a se orientar no espaço somente através da sinalização tátil no piso, mas devem ser orientados sobre o ambiente existente, para então optar ou não ao seu uso, combinando outros elementos. As paredes existentes nos corredores de circulação apresentam portas com degraus, o que dificulta a eleição dessas paredes como guia no deslocamento pelo aluno com deficiência visual.

Em relação à NBR 9050 (ABNT, 2004), conclui-se que a recomendação da largura mínima de $20 \mathrm{~cm}$ para a sinalização tátil direcional no piso é insuficiente para orientar o deslocamento de pessoas cegas ou com baixa visão, independentemente do uso das bengalas de rastreamento. Nesse caso, para que os dois pés da pessoa cega ou com baixa visão permaneçam sobre a sinalização tátil direcional durante a caminhada, há necessidade de ampliar a largura da faixa de sinalização. Ressalta-se que não caminhamos sobre uma linha, ou seja, uma pisada não se encontra no mesmo alinhamento da outra pisada.

Nesta pesquisa foi colocada a placa de sinalização tátil no piso de $25 \mathrm{~cm}$ x $25 \mathrm{~cm}$, mas verificou-se que a largura deve ser ampliada para no mínimo 45 cm, dado extraído de Panero e Zelnik (2002, p. 90) relativo à largura do quadril no limite superior $\left(95^{\circ}\right.$ percentil) de mulheres adultas. Essa ampliação poderá propiciar melhor usabilidade da sinalização pelas pessoas com deficiência visual, em especial nas interseções que sinalizam mudança de direção.

A recomendação de que "[...] quando o piso adjacente tiver textura, recomenda-se que a sinalização tátil direcional seja lisa [...]" (ABNT, 2004, p. 33) deve ser revista, pois se verificou na presente pesquisa que as placas antiderrapantes (ver Figura 12) oferecem maior segurança no uso.

Destaca-se que a sinalização tátil no piso pode ser utilizada pelas pessoas com baixa visão (com ou sem a bengala) que podem caminhar ao lado e/ou em cima da rota tátil. $O$ cego pode não rastrear a sinalização tátil no piso com a bengala, mas com os pés, e utilizar a bengala no rastreamento de outros obstáculos. Verificou-se que entre os professores de orientabilidade não há um consenso acerca das técnicas de uso da bengala de rastreamento pelas pessoas com deficiência visual e cada indivíduo pode receber um aprendizado diferente em relação às técnicas de orientabilidade e mobilidade.

Do mesmo modo como existem vários processos de levantamento de dados, existem vários modos de interpretação lógica destes dados.

Por isso, a ciência não pretende mais atingir uma verdade única e absoluta: suas conclusões não são consideradas como verdades dogmáticas, mas como formas de conhecimento [...]. (SEVERINO, 2000, p. 150).

O wayfinding system é composto de vários elementos que contribuem para a orientabilidade dos alunos com deficiência visual. Salienta-se que o aluno elegerá aqueles que o auxiliam na orientação de forma segura e eficaz. Os resultados das observações realizadas devem apoiar futuros projetos com qualidade ampliada de wayfinding destinados aos usuários com deficiência visual.

\section{Referências}

ABATE, T. P. Instrumentos de Avaliação PósOcupação (APO) Adaptados a Pré-Escolares Com Deficiência Física, Auditiva e Visual. São Paulo, 2011. Tese (Doutorado em Arquitetura e Urbanismo) - Faculdade de Arquitetura e Urbanismo, Universidade de São Paulo, São Paulo, 2011.

ABATE, T. P.; KOWALTOWSKI, D. C. C. K.; BERNARDI, N. Questões Éticas na Pesquisa em Avaliação Pós-Ocupação (APO). In: ENCONTRO NACIONAL DE TECNOLOGIA DO AMBIENTE CONSTRUÍDO, 15., Maceió, 2014. Anais... Maceió: ANTAC, 2014.

\section{ASSOCIAÇÃO BRASILEIRA DE NORMAS}

TÉCNICAS. NBR 9050: acessibilidade a

edificações, mobiliário, espaços e equipamentos urbanos. Rio de Janeiro: ABNT, 1985. 
ASSOCIAÇÃO BRASILEIRA DE NORMAS TÉCNICAS. NBR 9050: acessibilidade a edificações, mobiliário, espaços e equipamentos urbanos. Rio de Janeiro: ABNT, 1994.

\section{ASSOCIAÇÃO BRASILEIRA DE NORMAS}

TÉCNICAS. NBR 9050: acessibilidade a edificações, mobiliário, espaços e equipamentos urbanos. Rio de Janeiro: ABNT, 2004.

\section{ASSOCIAÇÃO BRASILEIRA DE NORMAS} TÉCNICAS. NBR 9050: acessibilidade a edificações, mobiliário, espaços e equipamentos urbanos. Rio de Janeiro: ABNT, 2015.

ARTHUR, P.; PASSINI, R. Wayfinding: people, signs and architecture. Ontario: McGraw-Hill Ryerson Ltd, 1992.

sBINS-ELY, V. H. et al. Avaliação Pós-Ocupação da Acessibilidade e Orientabilidade do Campus da Univali-São José/SC. In: SEMINÁRIO INTERNACIONAL - DEMANDAS SOCIAIS, INOVAÇÕES TECNOLÓGICAS E A CIDADE, São Paulo, 2004. Anais... São Paulo: NUTAU/USP, 2004.

BRASIL. Decreto Federal no 5.296 de 02 de dezembro de 2004. Regulamenta as Leis $\mathrm{n}^{\mathrm{os}}$ 10.048 , de 8 de novembro de 2000, que dá prioridade de atendimento às pessoas que especifica, e 10.098, de 19 de dezembro de 2000 , que estabelece normas gerais e critérios básicos para a promoção da acessibilidade das pessoas portadoras de deficiência ou com mobilidade reduzida, e dá outras providências. Diário Oficial da União, Brasília, DF, 2004.

BRASIL. Ministério da Saúde. Conselho Nacional de Saúde. Resolução no 466/2012. Diretrizes e normas regulamentadoras de pesquisas envolvendo seres humanos (revogou a Resolução no 196/1996, entre outras). Diário Oficial da União, Brasília, DF, 2012.

\section{CALORI, C. Signage and Wayfinding Design.}

Nova Iorque: Wiley John \& Sons, 2007.

CAMBIAGHI, S. Desenho Universal: métodos e técnicas para arquitetos e urbanistas. São Paulo: Editora Senac, 2007.

CORRAZE, J. As Comunicações Não-Verbais. Rio de Janeiro: Zahar, 1982.

DISCHINGER, M.; BINS-ELY, V. H. M. Como Criar Espaços Mais Acessíveis Para as Pessoas Com Deficiência Visual a Partir de Reflexões Sobre Nossas Práticas Projetuais? In: DESENHO Universal: caminhos da acessibilidade no Brasil. São Paulo: Annablume, 2010.
FELIPPE, J. Á. de M. et al. Caminhando Juntos: manual das habilidades básicas de orientação e mobilidade. Brasília: Ministério da Educação Secretaria de Educação Especial, 2004.

GIBSON, D. The Wayfinding Handbook: information design for public places. New York: Princeton, 2009.

GOLLEDGE, R. G. Wayfinfing Behavior: cognitive mapping and other spatial processes. Maryland: The Johns Hopkins University Press, 1999.

GÜNTHER, H.; ELALI, G. A.; PINHEIRO, J. de Q. A Abordagem Multimétodos em Estudos Pessoa-Ambiente: características, definições e implicações. In: PINHEIRO, J. de Q.; GÜNTHER, H. Métodos de Pesquisa nos Estudos Pessoa Ambiente. São Paulo: Casa do Psicólogo, 2008.

HAZELWOOD SCHOOL. Text Area. Disponível em: 〈http://www.hazelwood.glasgow.sch.uk〉. Acesso em: 3 mai. 2015.

HOFFMANN, S. B. Benefícios da Orientação e Mobilidade: estudo intercultural entre Brasil e Portugal. Benjamin Constant, Rio de Janeiro, v. 14, p. 11-16, dez. 1999.

HOLOVATUK, J. Trabalho de Sinalização. Disciplina de Design Gráfico. São Paulo: Centro Universitário Belas Artes de São Paulo, 2013.

KOWALTOWSKI, D. C. C. K. Arquitetura Escolar: o projeto do ambiente de ensino. São Paulo: Oficina de Texto, 2011.

LARAMARA. A Deficiência Visual Associada à Deficiência Múltipla e o Atendimento Educacional Especializado. São Paulo: Laramara, 2010.

LOPES, M. E. Ser Acessível é Ser Legal. In: GUGEL, M. A. et al. Deficiência no Brasil: uma abordagem integral dos direitos das pessoas com deficiência. Florianópolis: Obra Jurídica, 2007.

LYNCH, K. A Imagem da Cidade. São Paulo: Martins Fontes, 1997.

MASINI, E. F. S. O Perceber e o Relacionar-se do Deficiente Visual: orientando professores especializados. Revista Brasileira Educação Especial, Marília, v. 1, n. 1, p. 29-39, 1992.

MEUSER, P.; POGADE, D. Wayfinding and Signage: construction and design manual. Berlin: DOM Publishers, 2010.

70 Abate, T. P.; Kowaltowski, D. C. C. K. 
ONO, R.; MOREIRA, K. B. R. Acessibilidade Física, Segurança Contra Incêndio e Segurança Patrimonial: a importância da compatibilidade entre projetos. In: ALMEIDA PRADO, A. R. de; LOPES, M. E.; ORNSTEIN, S. W. (Orgs.). Desenho Universal: caminhos da acessibilidade no Brasil. São Paulo: Annablume, 2010.

PANERO, J.; ZELNIK, M. Dimensionamento Humano Para Espaços Interiores. Barcelona: Gustavo Gili, 2002.

PASSINI, R. Wayfinding in Architecture. Nova York: Van Nostrand Reinhold, 1984.

ROCHA, A. et al. Trabalho de Ergonomia da Disciplina de Ergonomia aplicada ao Design Gráfico. Centro Universitário Belas Artes de São Paulo. São Paulo, 2014.
SANTOS, A. J. de O.; CASTRO, S. A. de. Autoestima a Partir do Caminhar: orientação e mobilidade da pessoa com deficiência visual.

Benjamin Constant, Rio de Janeiro, v. 54, p. 2938, abr./jul. 2013.

SEVERINO, A. J. Metodologia do Trabalho Científico. São Paulo: Cortez, 2000.

\section{Agradecimentos}

Ao apoio relativo ao processo $n^{0}$ 2012/50369-8, à Fundação de Amparo à Pesquisa do Estado de São Paulo (Fapesp) pela concessão da bolsa de pósdoutorado, à Unicamp, à coordenadora da norma de sinalização tátil no piso (em elaboração), à revisora Simone Tostes, à direção da escola pesquisada e aos alunos especiais, não pelas suas deficiências, mas pelas suas virtudes.

Tania Pietzschke Abate

Faculdade de Engenharia Civil, Arquitetura e Urbanismo | Universidade Estadual de Campinas | Rua Saturnino de Brito, 224, Cidade Universitária | Campinas - SP - Brasil | CEP 13083-889 | Tel.: (11) 99410-004 | E-mail: tania.abate@terra.com.br

Doris Catharine Cornelie Knatz Kowaltowski

Departamento de Arquitetura e Construção, Faculdade de Engenharia Civil, Arquitetura e Urbanismo | Universidade Estadual de Campinas | Av. Albert Einstein, 951, Cidade Universitária Zeferino | Campinas - SP - Brasil | CEP 13083-852 | Tel.: (19) 3521 -2390 |

E-mail: doris@fec.unicamp.br

Revista Ambiente Construído

Associação Nacional de Tecnologia do Ambiente Construído

Av. Osvaldo Aranha, $99-3^{\circ}$ andar, Centro

Porto Alegre - RS - Brasil

CEP $90035-190$

Telefone: +55 (51) 3308-4084

Fax: +55 (51) 3308-4054

www.seer.ufrgs.br/ambienteconstruido

E-mail: ambienteconstruido@ufrgs.br 